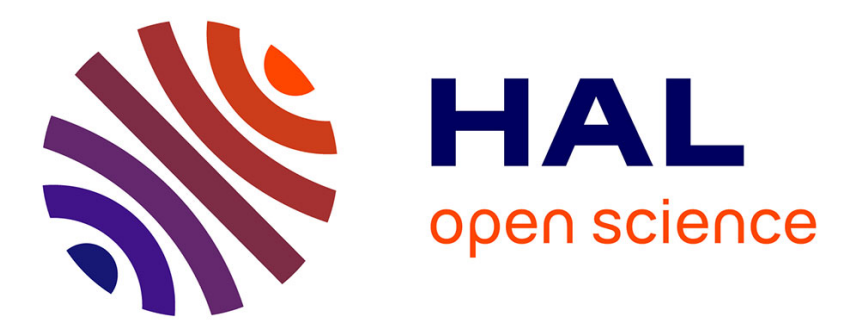

\title{
Preclinical characterization of alginate-Poly-L-Lysine encapsulated HepaRG for extracorporeal liver supply
}

Mattia Pasqua, Ulysse Pereira, Claire Lartigue, Jonathan Nicolas, Pascale Vigneron, Quentin Dermigny, Cécile Legallais

\section{- To cite this version:}

Mattia Pasqua, Ulysse Pereira, Claire Lartigue, Jonathan Nicolas, Pascale Vigneron, et al.. Preclinical characterization of alginate-Poly-L-Lysine encapsulated HepaRG for extracorporeal liver supply. Biotechnology and Bioengineering, 2021, 118 (1), 10.1002/bit.27583 . hal-02961888

\section{HAL Id: hal-02961888 \\ https://hal.science/hal-02961888}

Submitted on 11 Dec 2020

HAL is a multi-disciplinary open access archive for the deposit and dissemination of scientific research documents, whether they are published or not. The documents may come from teaching and research institutions in France or abroad, or from public or private research centers.
L'archive ouverte pluridisciplinaire HAL, est destinée au dépôt et à la diffusion de documents scientifiques de niveau recherche, publiés ou non, émanant des établissements d'enseignement et de recherche français ou étrangers, des laboratoires publics ou privés. 


\section{BIOTECHNOLOGY BIOENGINEERING}

\section{Preclinical characterization of alginate-Poly-L-Lysine encapsulated HepaRG for extracorporeal liver supply}

\begin{tabular}{|r|l|}
\hline Journal: & Biotechnology and Bioengineering \\
\hline Manuscript ID & Draft \\
\hline Wiley - Manuscript type: & Article \\
\hline Author: & n/a \\
\hline Complete List of Authors: & $\begin{array}{l}\text { Pasqua, Mattia; Universite de Technologie de Compiegne, CNRS, } \\
\text { Biomechanics \& Bioengineering } \\
\text { Pereira, Ulysse; Universite de Technologie de Compiegne, CNRS, } \\
\text { Biomechanics \& Bioengineering } \\
\text { de Lartigue, Claire; Universite de Technologie de Compiegne, CNRS, } \\
\text { Biomechanics \& Bioengineering } \\
\text { Nicolas, Jonathan; Universite de Technologie de Compiegne, CNRS, } \\
\text { Biomechanics \& Bioengineering } \\
\text { Vigneron, Pascale; Universite de Technologie de Compiegne, CNRS, } \\
\text { Biomechanics \& Bioengineering } \\
\text { Dermigny, Quentin; Universite de Technologie de Compiegne, CNRS, } \\
\text { Biomechanics \& Bioengineering } \\
\text { Legallais, Cecile; Université de Technologie de Compiègne, CNRS, } \\
\text { Biomechanics \& Bioengineering; Hôpital Paul Brousse, DHU Hepatinov, } \\
\text { Centre Hépato-Biliaire }\end{array}$ \\
\hline Key Words: & $\begin{array}{l}\text { Acute liver failure, Bioartificial liver, Liver tissue engineering, Bioreactor, } \\
\text { Organoid }\end{array}$ \\
\hline
\end{tabular}

\section{SCHOLARONE" Manuscripts}


Title:

Preclinical characterization of alginate-Poly-L-Lysine encapsulated HepaRG for extracorporeal liver supply

\section{Authors and affiliations:}

Mattia Pasqua, ${ }^{\text {a }}$ Ulysse Pereira, ${ }^{\text {a }}$ Claire de Lartigue, ${ }^{\text {a Jonathan Nicolas, }}{ }^{\text {a }}$ Pascale Vigneron, ${ }^{\text {a }}$ Quentin Dermigny, ${ }^{a}$ Cécile Legallais. ${ }^{a, b}$

aUMR CNRS 7338 Biomechanics \& Bioengineering, Université de technologie de Compiègne, Sorbonne Universités, Rue du Dr Schweitzer, 60203 Compiègne, France.

bDHU Hépatinov, 12 Avenue Paul Vaillant Couturier, 94800 Villejuif, France.

E-mail addresses and telephone numbers: mattia.pasqua@utc.fr (Mattia Pasqua)+33 344234423 , ulysse.pereira@utc.fr (Ulysse Pereira)+33 3442344 23, claire.de-lartigue@utc.fr (Claire de Lartigue)+33 3442344 23, jonathan.nicolas@etu.utc.fr (Jonathan Nicolas) + 33344234423 , pascale.vigneron@utc.fr (Pascale Vigneron)+33 3442344 23, quentin.dermigny@utc.fr (Quentin Dermigny)+33 3442344 23, cecile.legallais@utc.fr (Cécile Legallais)+33 344234423.

\section{Corresponding author:}

Cecile Legallais (cecile.legallais@utc.fr), +33 344234423

UMR CNRS 7338 Biomechanics \& Bioengineering, Université de technologie de Compiègne, Alliance Sorbonne Université, Rue du Dr Schweitzer, 60203 Compiègne, France 


\begin{abstract}
We recently demonstrated that HepaRG cells encapsulated into $1.5 \%$ alginate beads are capable of self-assembling into spheroids. They adequately differentiate into hepatocyte-like cells, with hepatic features observed at day 14 post-encapsulation required for external bioartificial liver applications. Preliminary investigations performed within a bioreactor under shear stress conditions and using a culture medium mimicking acute liver failure (ALF) highlighted the need to reinforce beads with a polymer coating. We demonstrated in a first step that a Poly-L-Lysine coating improved the mechanical stability, without altering the metabolic activities necessary for bioartificial liver applications (such as ammonia and lactate elimination). In a second step, we tested the optimized biomass in a newly-designed perfused dynamic bioreactor (PDB), in the presence of the medium model for pathological plasma for 6 hours. Performances of the biomass were enhanced as compared to the steady configuration, demonstrating its efficacy in decreasing the typical toxins of ALF. This type of bioreactor is easy to scale up as it relies on the number of micro-encapsulated cells, and could provide an adequate hepatic biomass for liver supply. Its design allows it to be integrated into a hybrid artificial/bioartificial liver setup for further clinical studies regarding its impact on ALF animal models.
\end{abstract}

\title{
Graphical abstract
}

\section{Keywords}

Acute liver failure, bioartificial liver, liver tissue engineering, bioreactor, organoid 


\section{Introduction}

Acute live failure (ALF) is a devastating syndrome involving severe injury to liver cells. It affects previously healthy individuals, and has a frequently fatal outcome (Keeffe, 2005). Following diagnosis of ALF, the optimal treatment is orthotopic liver transplantation (OLT) needed within a few days, making the availability of donor organs far lower than the demand (Van De Kerkhove et al., 2005). It is therefore urgent to develop new approaches capable of improving the management of ALF. In this sense, artificial livers (ALs) have been proposed as temporary therapy with purely detoxification functions. However, while analysis of clinical studies showed improvements in patients' clinical pictures, there was no such improvement in their survival (Kandiah \& Subramanian, 2019). On the other hand, bioartificial livers (BALs) also provide metabolic and synthetic activities, which could better replace the liver functions as extracorporeal therapy. The main goal of this therapy is either to allow the self-regeneration of the diseased liver, thus avoiding OLT and its long-term complications, or to serve as a bridge until a donor organ becomes available.

In the context of BALs, the bioreactor represents one of the key components as it hosts the active biomass. In general, a bioreactor is a volume where biochemical and biological processes take place (Catapano, G., Gerlach, 2007). A bioreactor should provide cells with adequate amounts of oxygen and nutrients, favour mass transfer between cells and fluids (the blood or plasma of the patient in ALF), and support the maintenance of cell viability and functions. To meet these requirements, the best option consists in designing a system in which convection (i.e. flux) from and to the plasma or surrounding medium takes place. Nevertheless, direct contact and shear stress may be harmful to the cells. Encapsulation of the biomass in semi-permeable hollow fibres or porous beads is thus often adopted so as to protect it from the hydrodynamic shear stress imposed by the flux (Rebelo et al., 2015) while simultaneously preserving cell activity (Pasqua et al., 2020), and promoting cell-cell interaction, thus enhancing hepatic-specific functions (Elkayam, Amitay-Shaprut, Dvir-Ginzberg, Harel, \& Cohen, 2006).

The fluidized bed bioreactor hosting alginate beads previously developed in our group (Doré \& Legallais, 1999) appeared to be a promising design and has been successfully driven to preclinical 
studies by others (Selden et al., 2017; Zhou et al., 2016) with HepG2 cells or primary porcine hepatocytes. However, with a very active biomass, such as HepaRG spheroids (6), we recently observed a phenomenon of severe deterioration of the alginate beads in the bioreactor, when they were exposed to a human equivalent pathological plasma medium (containing some ALF toxins), leading to an unacceptable loss of biomass and the associated risk of cells' release to the patient. This phenomenon has already been noted by other authors (Simó, Fernández-Fernández, Vila-Crespo, Ruipérez, \& Rodríguez-Nogales, 2017) and was attributed to the presence of $\mathrm{Ca}^{2+}$ chelators (such as lactate) or anti-gelling cations $\left(\mathrm{Na}^{+}\right.$and $\left.\mathrm{Mg}^{2+}\right)$ in the surrounding media. For safety reasons, reinforcement of the alginate beads by means of an external coating becomes essential when using encapsulated HepaRG or other very active hepatocyte constructs in view of clinical application.

Several types of coatings have been proposed to date in the literature (De Vos, De Haan, \& Van Schilfgaarde, 1997; Edwards-Lévy \& Lévy, 1999; Joly et al., 1997; Simó et al., 2017). They are often developed to formulate capsules, whose core is liquid in contrast to beads. These techniques involve either ionic or covalent (Dusseault et al., 2005; Lou et al., 2017; Simó et al., 2017) interactions between the surface of the alginate gel and the coating materials. In particular, ionic cross-linking coating of the beads can be performed thanks to the alginate's ability (with a negatively charged surface) to form strong electrostatic complexes with polycations (Simó et al., 2017). Of the latter, the natural polymers Poly-L-lysine (PLL) and Poly-L-ornithine (PLO) are most frequently used to reinforce the mechanical stability of the alginate beads (Bhujbal, Paredes-Juarez, Niclou, \& de Vos, 2014; Du \& Yarema, 2014; Goosen, O’Shea, Gharapetian, Chou, \& Sun, 1985; Simó et al., 2017). However, to our knowledge, it has never been applied in the context of an external bioartificial liver application. On the other hand, an external coating modifies the permeability of the beads without heavily affecting the cells' metabolic performances and viability, as observed by Capone et al. using encapsulated HepG2/C3A in alginate-PLL beads (Capone et al., 2013).

Therefore, in this study we proposed analysing the impact of a PLL coating on alginate beads' physical and mechanical properties, and its role on encapsulated HepaRG cells' metabolic performances. The encapsulated biomass was then transferred to a perfused bioreactor to mimic 
clinical therapy, demonstrating the features necessary for clinical use of BAL, in terms of cell metabolic activity and therapy safety.

\section{Materials and Methods}

2.1. $2 \mathrm{D}$ HepaRG cell culture

HepaRG cells from Biopredic (Rennes, France) were expanded into two-dimensional (2D) monolayers following the indications given by the supplier. The cells were passaged every 2 weeks until passage 18, with HepaRG proliferation culture medium (William's E-WE-, with sodium bicarbonate, without L-glutamine and phenol red, Sigma-Aldrich, with added Biopredic 710 proliferation media) replenished three times a week. The cultures were maintained in a humidified environment at $37^{\circ} \mathrm{C}, 5$ $\% \mathrm{CO}_{2}$. Cells were then detached with trypsin-EDTA $0.25 \%$ (ThermoFisher scientific) from the culture flasks and used for the encapsulation process.

2.2. Alginate microencapsulation and PLL coating The cells were mixed in sodium alginate (Manucol-LKX from FMC BioPolymer, Guluronic / Mannuronic ratio 30-70, viscosity $\operatorname{Cps}(1 \%) 60-170) 1.5 \%(\mathrm{w} / \mathrm{v})$, sterilized with successive filtrations $(0.8,0.45$, and $0.22 \mu \mathrm{m}$ pore size membrane filters). The encapsulation was performed using a homemade system based on a coaxial airflow extrusion method (Gautier et al., 2011). Briefly, the alginate solution ( $1 \mathrm{~mL}$ ) containing cells (5 million) was rapidly extruded through a $24 \mathrm{G}$ nozzle and the droplets fell into a gelation bath ( $\mathrm{NaCl} 154 \mathrm{mM}$, HEPES $10 \mathrm{mM}, \mathrm{CaCl}_{2} 115 \mathrm{mM}, \mathrm{pH}$ 7.4). This small volume ensured both even distribution of the cells throughout the beads and the absence of empty beads. The droplets produced were left to settle for $15 \mathrm{~min}$ in the gelation bath to ensure gel formation. Then, the microbeads were washed three times in WE medium and resuspended in HepaRG proliferation culture medium. At day 1 post-encapsulation, a PLL coating (Poly-L-lysine hydrobromide, molecular weight 30,000-70,000, Sigma-Aldrich) was added to the beads, relying on the protocol developed by Khanna et al. (Khanna, Larson, Moya, Opara, \& Brey, 2012) with few modifications. Briefly, alginate beads containing cells were washed three times in WE medium, resuspended in a $0.1 \%$ PLL solution and then transferred to culture dishes in continuous orbital shaking (60 rpm), for 30 minutes. After that, the beads were washed again 3 times with WE medium. Finally, they were incubated with proliferation culture medium and transferred to culture dishes in 
continuous orbital shaking in a humidified environment at $37^{\circ} \mathrm{C}, 5 \% \mathrm{CO}_{2}$ until day 14 . The HepaRG proliferation culture medium was replaced every 2 days.

2.3. Culture setups and experimental design

The hepatic biomass was tested in two different culture conditions (shaken and perfused), shown in Figure 1A. Experiments designed to assess the cells' metabolic performance are detailed in Figure 1B. At the end of each experiment, microbeads were recovered and assessed for cell viability. The quantity of marker analysed was calculated and normalized by the number of hours of incubation and the number of cells seeded. Moreover, in order to avoid artefacts, all the metabolic activities tested were normalized by the quantity present at time zero and by carrying out controls with empty microbeads. Any influence of the empty beads on the cellular activities assessed was therefore corrected during analysis of the results.

\section{Figure 1}

2.4. Viability, metabolic and xenobiotic tests

\subsubsection{Cell viability}

Aliquots of encapsulated cells were collected and a Live/Dead assay was performed following the manufacturer's instructions (Invitrogen ${ }^{\mathrm{TM}} \mathrm{LIVE} / \mathrm{DEAD}^{\mathrm{TM}}$ Viability/Cytotoxicity Kit, for mammalian cells, ThermoFisher). The nuclei were stained with Hoechst33342 dye ( $3 \mu \mathrm{M})$. The encapsulated cells were visualized by confocal microscopy.

\subsubsection{Albumin synthesis}

Albumin synthesis was quantified using the ELISA test (Human Albumin ELISA kit, Bethyl Laboratories, Inc.). Analyses were performed in conformity with the manufacturer's instructions.

\subsubsection{ICG assay}

The indocyanine green (ICG, Sigma-Aldrich) assay was carried out as previously described (Pasqua et al., 2020). Briefly, beads were incubated with ICG $1 \mathrm{mg} / \mathrm{mL}$ in proliferation culture medium for 30 minutes at $37{ }^{\circ} \mathrm{C}$ and $5 \% \mathrm{CO}_{2}$ to favour the uptake of ICG by the transporters OATP1B3 (solute carrier organic anion transporter family member 1B3) and NTCP (sodium/taurocholate cotransporting-polypeptide) (Graaf et al., 2011). ICG was then removed by washing with WE five times and the microbeads were incubated with proliferation culture medium for 1 hour to study the release of 
ICG by the transporters MDR3 (multidrug-resistance protein 3) and MRP2 (multidrug-resistanceassociated protein 2) (Cusin et al., 2017). The quantity of ICG released was obtained by measuring its absorbance (at $820 \mathrm{~nm}$ ) based on a standard curve generated from a solution containing ICG $1 \mathrm{mg} / \mathrm{mL}$.

\subsubsection{EROD assay}

The activity of the cytochrome P450-1A1/2 (CYP1A1/2) was studied with the ethoxyresorufin-Odeethylase (EROD) assay as previously described (Diaz, 2000; Pasqua et al., 2020). The microbeads were incubated in ethoxyresorufin $(10 \mu \mathrm{M})$, prepared in $\mathrm{WE}$, for 1 hour at $37^{\circ} \mathrm{C}$. The substrate included salicylamide $(3 \mathrm{mM})+$ dicumarol $(40 \mu \mathrm{M})$ in order to inhibit phase II enzymes. The substrate was converted into resorufin then measured in the supernatant by spectrometry (excitation wavelength of $535 \mathrm{~nm}$ and emission wavelength of $595 \mathrm{~nm}$, Spectafluor Plus, TECAN). The standard curve was generated with a solution containing exogenous resorufin $(10 \mu \mathrm{M})$.

\subsubsection{Ammonia and lactate quantification}

Supernatants of test medium and pathological plasma medium were collected and analysed with Indiko $^{\mathrm{TM}}$ (Thermofisher) to determine the concentration of ammonia and Lactate Assay Kit (SigmaAldrich) to measure the concentration of lactate, following the indications reported by the supplier.

2.5. Physical and mechanical characterization of empty alginate microbeads

2.5.1.PLL distribution in the alginate beads

In order to visualize the distribution of the PLL on the empty alginate beads (i.e. without cells, produced using the same protocol previously presented), PLL staining with rhodamine was performed. Firstly, we prepared an NHS-Rhodamine (Thermofisher) solution in DMSO at concentration 50 $\mathrm{mg} / \mathrm{mL}$ and a solution of sodium bicarbonate at $8.3 \mathrm{mg} / \mathrm{mL}$ in double distilled $\mathrm{H}_{2} \mathrm{O}$, pH 8.2. PLL was solubilized in the sodium bicarbonate solution at a final concentration of $0.1 \% \mathrm{w} / \mathrm{v}$, containing NHSRhodamine solution at a final concentration of $500 \mu \mathrm{g} / \mathrm{mL}$. In order to favour the conjugation between the NHS-Rhodamine and epsilon- $\mathrm{NH}_{2}$ of lysine residues, the solution was incubated in the dark for 3 hours at room temperature. The control solution did not contain PLL. After that, the PLL coating was achieved by putting the beads in contact with this solution, according to the protocol already described. The beads were finally washed 3 times in DPBS and visualized by confocal microscopy. The thickness of the external coating was measured using Image $1.52 \mathrm{~h}$ software. 


\subsubsection{Mechanical characterization}

The elastic modulus of the outer surface of the empty beads was measured by microindentation (ChiaroOptics 11, Amsterdam, Netherlands). The probes used for surface indentation had a radius of around $25 \mu \mathrm{m}$ and a spring constant of $0.5 \mathrm{~N} / \mathrm{m}$ and $5 \mathrm{~N} / \mathrm{m}$, for pure alginate beads and PLL coated ones, respectively. Before testing, the optical sensitivity and the geometrical factor were calibrated by indenting a hard surface (e.g. glass slide). Alginate beads were deposited on a glass slide and then immersed in proliferation culture medium. The probe was placed in contact with a single bead and a maximal indentation of $3 \mu \mathrm{m}$ was applied. All experiments were performed at room temperature. For each condition, about 15-20 curves (load vs indentation depth) were acquired. Data were analysed using DataViewer 2.2 software (Optics 11, Amsterdam, Netherlands) and the Hertzian theory, which provided the elastic modulus of the indented area.

\subsubsection{Bead permeability}

The permeability of empty alginate beads, with and without a PLL coating, was studied by putting them in contact with fluorescent molecules of different molecular weights and sizes on day 13 postencapsulation process, in orbital agitation. On day 14, the beads were washed once in WE medium and visualized using confocal microscopy.

\section{Table 1}

\subsection{Statistical analysis}

All the results presented were obtained from at least three independent cultures $(\mathrm{N} \geq 3)$. The statistical analysis was performed using GraphPad InStat v.3.10. Unpaired data were subjected to a Mann Whitney test or Dunn's Multiple Comparisons Test, with a $95 \%$ confidence level considered significant. P values are presented as follows: no stars: $\mathrm{p}>0.05 ;{ }^{* *} \mathrm{p}<0.01 ;{ }^{* *} \mathrm{p}<0.001$.

\section{Results}

3.1. Physical and mechanical characterization of the PLL coated beads This step was performed with empty beads that were produced following the same protocol as that exposed in the Materials \& Methods section for cell encapsulation.

3.1.1.PLL coating and distribution around the alginate beads 
On day 1, after PLL coating, a variation in the sphericity of the beads was visible (Figure 2A), due to a shrinking effect. The diameter of the beads decreased by about $20 \%$, from $949 \pm 49 \mu \mathrm{m}$ postencapsulation to $785 \pm 25 \mu \mathrm{m}$ after PLL coating. The diameter of the beads, with or without a PLL coating, then remained stable until the end of the experiment.

Phase contrast and confocal microscopy clearly showed that PLL was distributed only on the surface of the alginate beads, causing a slight morphological variation on their periphery (Figure 3). The thickness of the external coating was around $14.4 \pm 6.4 \mu \mathrm{m}$.

\subsubsection{Mechanical properties of the PLL layer}

The mechanical properties of the surface of single empty beads were assessed by microindentation. The results showed a significant increase in the elastic modulus of the external area of the beads coated with PLL, 6.6 times higher in comparison with the pure alginate condition (Figure 2B), ensuring surface mechanical reinforcement and thus better stability.

\section{Figure 2}

\subsubsection{Bead permeability}

The porosity of empty alginate beads with or without a PLL coating was evaluated by means of exposure to different fluorescent markers of increasing size (Table 1). The microscope observations (Figure 3) did not show any measurable differences between either condition. Albumin, IgG, and $41 \mathrm{~nm}$ diameter NPs were able to penetrate the core of the beads. Larger NPs were fully retained entirely outside the beads, and did not colour their inner part green. The cut-off threshold for both conditions was thus between $41 \mathrm{~nm}$ and $103 \mathrm{~nm}$.

\section{Figure 3}

\subsection{Viability of encapsulated cells over 14 days}

The production of alginate beads with homogeneous cell distribution was achieved with success and no empty beads were visible after the cell encapsulation process. We estimated approximately 1100 beads per encapsulation batch ( $1 \mathrm{~mL}$ of alginate solution) by counting them with the optical microscope. As the initial biomass was 5 million cells $/ \mathrm{mL}$ of alginate, we calculated approximately 
4500 cells per bead. As previously observed on empty beads, the PLL coating provoked a shrinking effect of about $20 \%$ in the diameter of the beads.

The number of viable hepatocytes (Figure 4, in green) within the microbeads remained high over time, as very few dead cells (Figure 4, red stained nuclei) were observed, in comparison with the negative control where cells were killed by ethanol $70 \%$ exposure. The PLL coating did not seem to affect cell viability. Therefore, neither the long-time culture nor the coating process had any significant impact on cellular viability. Qualitatively from day 1 to day 14, a phenomenon of cell-cell aggregation likely occurred, visible through the incorporation of Calcein-AM by living cells. We observed very similar results in beads without a PLL coating (data not shown). It should be noted that, once the PLL coating was present, the beads became opaque making the encapsulated cells difficult to visualize under the light microscope.

\section{Figure 4}

Albumin production is considered to be a quality marker for the hepatic biomass in a bioreactor (Van Wenum et al., 2014). We therefore evaluated the secretion rate of albumin in order to quantitatively determine biomass functionality over the 14 days of culture (Figure 1, Supplementary data). Albumin secretion rate increased from $0.20 \pm 0.09$ and $0.17 \pm 0.05 \mu \mathrm{g} / \mathrm{h} / 10^{6}$ at day 1 for the conditions without and with PLL respectively, to $0.49 \pm 0.15$ and $1.01 \pm 0.21 \mu \mathrm{g} / \mathrm{h} / 10^{6}$ at day 14 . This increase was significant for the two weeks of culture $(\mathrm{p}<0.01)$ when the PLL coating was present.

\subsection{Metabolic activity of cells on day 14}

To investigate the impact of the PLL coating on the cells' metabolic performance, we designed culture media with increasing complexity in their composition (Table 2), in order to progressively mimic a clinical condition of ALF human plasma.

\section{Table 2}

The first batch of encapsulated cells was first evaluated in the proliferation culture medium (Table 3). In the presence of the PLL coating, there was a slight tendency for metabolic activities to decrease, but this was only significant for CYP1A1/2, 3.5 times lower $(\mathrm{p}<0.01)$. However, even in the presence of a PLL coating, the cells remained metabolically active. 


\section{Table 3}

The same biomass was then used in test medium (Table 3 ) to measure the rate of albumin production, and the ability of cells to detoxify typical ALF toxins (ammonia and lactate elimination rates). The metabolic activities measured remained equivalent between both conditions (PLL coated vs uncoated).

The second batch of biomass was tested on the equivalent pathological plasma medium, cultivating encapsulated cells in shaken culture and in a perfused dynamic bioreactor (PDB), the biological component of the BAL developed in our laboratory. The aim was to compare the two culture setups and above all to reproduce BAL therapy, using an ALF-human plasma model and a perfusion system. Only the condition "alginate beads with PLL coating" could be exploited with this medium, as without PLL we observed severe bead deteroration.

Importantly, before testing in an equivalent pathological medium, the biomass was exposed to an equivalent plasma medium (HepaRG proliferation culture medium supplemented with $70 \mathrm{~g} / \mathrm{L}$ bovine serum albumin-BSA-, to mimic healthy human plasma in a total protein concentration), in order to reproduce the BAL priming with a view to clinical therapy. After that, cells were exposed to the equivalent pathological plasma medium for 6 hours.

The ability of the cells to produce albumin and detoxify these toxins is shown in Figure 5. While the albumin secretion rate (Figure $5 \mathrm{~A}$ ) was favoured in the shaken culture, ammonia detoxification (Figure 5B) and lactate clearance rates (Figure 5C) were stronger in the PDB setup.

\section{Figure 5}

At the end of the experiments, we evaluated the cell viability for both batches of cells. Viability remained high and stable overall for all conditions (Figure 2, Supplementary data). As previously mentioned, a phenomenon of cell-cell aggregation inside the beads was observed.

\section{Discussion}

We recently demonstrated the benefits of using HepaRG cells, capable of differentiating into hepatocyte-like cells (Cerec et al., 2007), encapsulated in alginate beads as the biomass for BAL (Pasqua et al., 2020). The present study therefore focused on the transfer of this biomass within a 
bioreactor compatible with BAL therapy. However, during the first experiments carried out in an ALF-human equivalent pathological plasma medium, we observed severe and unacceptable deterioration of the beads. We thus highlighted the need to reinforce the mechanical properties of the biomaterial.

We hypothesized that the deterioration was due to the presence of an excess of BSA and lactate in the surrounding medium, both capable of sequestrating calcium ions involved in the formation of the alginate gel. A similar deterioration effect was observed by Benson et al. (Benson, Papas, Constantinidis, \& Sambanis, 1997). In the literature, a PLL coating has been proposed to increase the structural stability of alginate beads and to limit access of the immune system to the beads/capsules (Benson et al., 1997; Capone et al., 2013; Berit L. Strand, Coron, \& Skjak-Braek, 2017). For this specific application, if PLL was not additionally coated with a layer of alginate (i.e. alginate-PLLalginate beads), it demonstrated immunogenicity (Berit L. Strand et al., 2017) and caused fibrotic overgrowth when implanted in mice (B. L. Strand et al., 2001). While this additional layer of alginate on the PLL coating appeared essential for implantation of the encapsulated cells, this is not the case for extracorporeal circulation devices such as BAL therapy. In fact, most BAL devices, including the one developed in our laboratory (Figaro, Pereira, Dumé, et al., 2015), include a plasma filter to separate the plasma from the elements formed of the blood. As a result, the cells of the immune system are discarded upstream, before making contact with the therapeutic biomass, making activation of a specific immune response unlikely.

Preliminary experiments conducted on our medium model of pathological plasma showed that a PLL coating successfully prevented beads from deteriorating. We analysed the physical/mechanical characteristics of the biomaterial with and without a PLL coating. Looking at the morphology, we observed an immediate and stable reduction of about $20 \%$ in the beads' diameter after a PLL coating was applied, without any significant impact on cell viability. Analysis of the distribution of PLL showed that it was not able to enter the core of the alginate bead, remaining only on its shell. This phenomenon was also reported by Yahia et al. (Tam et al., 2011). In addition, the presence of the coating significantly increased the elastic modulus of the external area of the beads, making them 
resistant to deterioration. Regarding the porosity, we did not notice any measurable difference between beads with or without a PLL coating. Both conditions had a cut-off between 41 and 103nm.

Fluorescent albumin, $\mathrm{IgG}$, and nanoparticles of $41 \mathrm{~nm}$ in diameter could effectively enter the beads, after 24 hours' incubation, but they were impermeable to polystyrene nanoparticles of $103 \mathrm{~nm}$, as also observed by Tran et al. (Tran et al., 2014). Of note, some large molecules physiologically produced by hepatocytes fell within this cut-off value (such as fibrinogen, about $48 \mathrm{~nm}$ in hydrodynamic diameter (Bratek-Skicki, Zeliszewska, \& Ruso, 2016)) and their transfer between the polymer network and the surrounding medium could be hindered. Importantly, considering that liver sinusoidal endothelial cells (the cells that delimit the space of Disse together with hepatocytes, controlling the trafficking of macromolecules), have fenestrae with diameter between 50-300nm (Wisse, 2002), the cut-off of our beads fitted well with this physiological range. On the basis of our results, we concluded that a large set of molecules produced by the encapsulated hepatocytes (and those present in the culture medium) could leave (and enter) the alginate matrix, an essential factor for BAL therapy.

We then evaluated whether or not the presence of this additional polymer could affect the cells' metabolic performance. According to our observations, encapsulated cell viability was affected neither by the long-term culture of cells nor by the presence of PLL. Noticeably, one of the markers of liver cell functionality is albumin production. Monitoring this secretion between the two conditions (with or without PLL) in shaken conditions showed a progressive increase throughout the culture up to day 14 with an advantage for PLL coated beads, corresponding to efficient HepaRG differentiation. On day 14, we tested different metabolic activities required for BAL applications, such as ammonia and lactate elimination. We were not able to measure any significant difference between either condition, with the exception of a downward trend in xenobiotic activities, and more precisely for CYP1A1/2, when the coating was present. This might be due to an increase in the beads' core stiffness after shrinking. Chen et al. (Chen, Khetani, Lee, Bhatia, \& Van Vliet, 2009) effectively cultured rat hepatocytes on polyelectrolyte multilayers and found that albumin production and CYP1A activity decreased with increasing substrate stiffness. 
In the next step, we tested the functionality of cells on an equivalent pathological plasma medium, reproducing clinical therapy. We estimated that this biomass (alginate-PLL encapsulated HepaRG) had the characteristics necessary for extracorporeal BAL application. To support this hypothesis, we decided to use it in the PDB, compatible with the system developed in our laboratory (Figaro, Pereira, Rada, et al., 2015). Similar bioreactor designs, such as stirred-tank bioreactors, have long been used in large-scale culture of mammalian cells to provide an environment allowing control of oxygen, $\mathrm{pH}$, and the continuous addition and removal of medium. They are commonly used for the large-scale production of spheroids that can be maintained for extended periods (Tostões et al., 2012), classically used in toxicological applications (Rebelo et al., 2015). Moreover, Dr. Nyberg's group, who recently proved the beneficial role of the spheroid-reservoir BAL in treating pigs experiencing posthepatectomy ALF (Chen HS., Joo DJ., Shaheen M., Li Y., WangY., Yang J., Nicolas CT., Predmore K., Amiot B., Michalak G., Mounajjed T., Fidler J., Kremers WK., 2019), highlighted how an impeller-agitated bioreactor could support high volumes of hepatocyte spheroid solutions, with a simple and compact design that is easy to scale up for BAL clinical applications (McIntosh, Corner, Amiot, \& Nyberg, 2009). Overall, we consider that the PDB hosting alginate-PLL encapsulated HepaRG fitted these important criteria and, to our knowledge, it is the first time that this design has been used for BAL applications.

HepaRG matured in PLL alginate beads were able to produce proteins, detoxify ammonia and metabolize lactate to levels comparable or superior to other published works with similar cells (Nibourg et al., 2013) or primary porcine hepatocytes in the AMC-BAL (Poyck et al., 2007). The latter two activities were superior in the PDB compared to the shaken conditions setup linked with net cellular activity, as the results were normalized by the controls with empty alginate-PLL beads. It is difficult to assume that the perfusion of medium was the key element for the enhanced activity observed in PDB, given the very low perfusion flow in our experiments. We thus hypothesized that such improvement was promoted by increased oxygenation of the culture medium. The latter is associated with the synergistic role of orbital shaking culture and the increased exchange surface between the medium and the external environment in PDB rather than the shaken setup. Adam et al. 
assumed that improved oxygenation when cultivating HepaRG cells under shaking conditions would lead to mitochondrial biogenesis, improving hepatic differentiation and cell metabolic activity (such as ammonia detoxification and CYP-3A4 activity) (Adam et al., 2018). In addition, the role of oxygen on HepaRG differentiation and functions is crucial, as observed by van Wenum et al., where the authors demonstrated that culturing HepaRG in hyperoxia (i.e. $40 \% \mathrm{O}_{2}$ ) enhanced cell differentiation and improved metabolic functions (such as ammonia detoxification and CYP3A4 activity), when compared with normoxia conditions (i.e. $21 \% \mathrm{O}_{2}$ ) (van Wenum et al., 2018).

In PDB, we noticed a significant decrease of around $40 \%$ in initial ammonia concentrations and around $30 \%$ in lactate after 6 hours of cell perfusion in the equivalent pathological plasma medium. At the end of the experiment, we did not notice any deterioration of the alginate-PLL beads or loss of cells, observing the supernatant on bright field microscopy. This feature, together with the presence of filters that avoid cells escaping from the bioreactor, is of key importance for conducting safe treatment for the patient.

\section{Conclusion}

We adapted the HepaRG biomass encapsulated in alginate beads to the conditions of ALF therapy by adding a PLL coating. This coating covered the shell of the beads without altering the porosity or viability of the cells. In terms of metabolic activity, we measured very interesting performances in line with those required of BAL in the treatment of ALF. The next step will be to implement the PDB in the BAL, currently being optimized in our laboratory, and start the preclinical experiments on rodent ALF models.

\section{Acknowledgement}

We thank Dr Antonietta Messina and Dr Anne Dubart-Kupperschmitt (INSERM U1193) for the fruitful discussion throughout this work, and Augustin Lerebours, for his technical assistance. The HepaRG cell line, media and supplements used were supported by Biopredic International (funded by ANR 16-RHUS-0005 in the framework of the iLite programme), for which the authors express their appreciation. This cell line was patented by Inserm under number WO 03/004627. 


\section{References}

Adam, A. A. A., van der Mark, V. A., Donkers, J. M., Wildenberg, M. E., Oude Elferink, R. P. J., Chamuleau, R. A. F. M., \& Hoekstra, R. (2018). A practice-changing culture method relying on shaking substantially increases mitochondrial energy metabolism and functionality of human liver cell lines. PLoS ONE, 13(4), 1-19. https://doi.org/10.1371/journal.pone.0193664

Benson, J. P., Papas, K. K., Constantinidis, I., \& Sambanis, A. (1997). Towards the development of a bioartificial pancreas: Effects of poly-L- lysine on alginate beads with BTC3 cells. Cell Transplantation, 6(4), 395-402. https://doi.org/10.1016/s0963-6897(97)00044-4

Bhujbal, S. V., Paredes-Juarez, G. A., Niclou, S. P., \& de Vos, P. (2014). Factors influencing the mechanical stability of alginate beads applicable for immunoisolation of mammalian cells. Journal of the Mechanical Behavior of Biomedical Materials, 37, 196-208. https://doi.org/10.1016/j.jmbbm.2014.05.020

Bratek-Skicki, A., Zeliszewska, P., \& Ruso, J. M. (2016). Fibrinogen: A journey into biotechnology. Soft Matter, 12(42), 8393-8653. https://doi.org/10.1039/C6SM01895E

Capone, S. H., Dufresne, M., Rechel, M., Fleury, M. J., Salsac, A. V., Paullier, P., ... Legallais, C. (2013). Impact of Alginate Composition: From Bead Mechanical Properties to Encapsulated HepG2/C3A Cell Activities for In Vivo Implantation. PLoS ONE, 8(4). https://doi.org/10.1371/journal.pone.0062032

Catapano, G., Gerlach, J. C. (2007). Bioreactors for liver tissue engineering. (R. R. \& E. C. N Ashammakhi, Ed.), Topics in tissue engineering. Oulu, Finlande: Oulu University.

Cerec, V., Glaise, D., Garnier, D., Morosan, S., Turlin, B., Drenou, B., ... Corlu, A. (2007). Transdifferentiation of hepatocyte-like cells from the human hepatoma hepaRG cell line through bipotent progenitor. Hepatology, 45(4), 957-967. https://doi.org/10.1002/hep.21536

Chen, A. A., Khetani, S. R., Lee, S., Bhatia, S. N., \& Van Vliet, K. J. (2009). Modulation of hepatocyte phenotype in vitro via chemomechanical tuning of polyelectrolyte multilayers. Biomaterials, 30(6), 1113-1120. https://doi.org/10.1016/j.biomaterials.2008.10.055

Chen HS., Joo DJ., Shaheen M., Li Y., WangY., Yang J., Nicolas CT., Predmore K., Amiot B., Michalak G., Mounajjed T., Fidler J., Kremers WK., N. S. (2019). Randomized Trial of Spheroid Reservoir 
Bioartificial Liver in Porcine Model of Posthepatectomy Liver Failure. Hepatology, 69(1), 329342. https://doi.org/10.1002/hep.30184

Cusin, F., Azevedo, L. F., Bonnaventure, P., Desmeules, J., Daali, Y., \& Pastor, C. M. (2017). Hepatocyte Concentrations of Indocyanine Green Reflect Transfer Rates Across Membrane Transporters, 171-178. https://doi.org/10.1111/bcpt.12671

De Vos, P., De Haan, B., \& Van Schilfgaarde, R. (1997). Effect of the alginate composition on the biocompatibility of alginate-polylysine microcapsules. Biomaterials, 18(3), 273-278. https://doi.org/10.1016/s0142-9612(96)00135-4

Diaz, G. J. (2000). Basolateral and canalicular transport of xenobiotics in the hepatocyte: A review. Cytotechnology, 34(3), 225-236. https://doi.org/10.1023/A:1008152205697

Doré, E., \& Legallais, C. (1999). A new concept of bioartificial liver based on a fluidized bed bioreactor. Therapeutic Apheresis, 3(3), 264-267. https://doi.org/10.1046/j.1526-0968.1999.00152.x

Du, J., \& Yarema, K. J. (2014). Cell Microencapsulation for Tissue Engineering and Regenerative Medicine. Micro-and Nanoengineering of the Cell Surface, 23, 215-239. https://doi.org/110.1016/B978-1-4557-3146-6.00010-6

Dusseault, J., Leblond, F. A., Robitaille, R., Jourdan, G., Tessier, J., Ménard, M., .. Hallé, J. P. (2005). Microencapsulation of living cells in semi-permeable membranes with covalently cross-linked layers. Biomaterials, 26(13), 1515-1522. https://doi.org/10.1016/j.biomaterials.2004.05.013

Edwards-Lévy, F., \& Lévy, M. C. (1999). Serum albumin-alginate coated beads: Mechanical properties and stability. Biomaterials, 20(21), 2069-2084. https://doi.org/10.1016/s0142-9612(99)00111-8

Elkayam, T., Amitay-Shaprut, S., Dvir-Ginzberg, M., Harel, T., \& Cohen, S. (2006). Enhancing the drug metabolism activities of $\mathrm{C} 3 \mathrm{~A}$-a human hepatocyte cell line- by tissue engineering within alginate scaffolds. Tissue Engineering, 12(5), 1357-1368. https://doi.org/10.1089/ten.2006.12.1357

Figaro, S., Pereira, U., Dumé, A. S., Rada, H., Capone, S., Bengrine, A., ... Legallais, C. (2015). SUPPLIVER: Bioartificial supply for liver failure. Irbm, 36(2), 101-109. https://doi.org/10.1016/j.irbm.2015.01.010

Figaro, S., Pereira, U., Rada, H., Semenzato, N., Pouchoulin, D., \& Legallais, C. (2015). Development and validation of a bioartificial liver device with fluidized bed bioreactors hosting alginate- 
encapsulated hepatocyte spheroids. Proceedings of the Annual International Conference of the IEEE Engineering in Medicine and Biology Society, EMBS, 1335-1338. https://doi.org/10.1109/EMBC.2015.7318615

Gagnon, P., Nian, R., Leong, D., \& Hoi, A. (2015). Transient conformational modification of immunoglobulin G during purification by protein A affinity chromatography. Journal of Chromatography A, 1395, 136-142. https://doi.org/10.1016/j.chroma.2015.03.080

Gautier, A., Carpentier, B., Dufresne, M., Vu Dinh, Q., Paullier, P., \& Legallais, C. (2011). Impact of alginate type and bead diameter on mass transfers and the metabolic activities of encapsulated c3a cells in bioartificial liver applications. European Cells and Materials, 21(0), 94-106. https://doi.org/10.22203/ecm.v021a08

Goosen, M. F. A., O’Shea, G. M., Gharapetian, H. M., Chou, S., \& Sun, A. M. (1985). Optimization of microencapsulation parameters: Semipermeable microcapsules as a bioartificial pancreas. Biotechnology and Bioengineering, 27(2), 146-150. https://doi.org/10.1002/bit.260270207

Graaf, W. De, Häusler, S., Heger, M., Ginhoven, T. M. Van, Cappellen, G. Van, Bennink, R. J., ... Stieger, B. (2011). Transporters involved in the hepatic uptake of and indocyanine green Tcmebrofenin. Journal of Hepatology, 54(4), 738-745. https://doi.org/10.1016/j.jhep.2010.07.047

Joly, A., Desjardins, J.-F., Fremond, B., Desille, M., Campion, J.-P., Malledant, Y., ... Clement, B. (1997). Survival, proliferation, and functions of porcine hepatocytes encapsulated in coated alginate beads: a step toward a reliable bioartificial liver. Transplantation, 63(6), 795-803. https://doi.org/10.1097/00007890-199703270-00002

Kandiah, P. A., \& Subramanian, R. M. (2019). Extracorporeal devices. Critical Care Clinics, 35(1), 135-150. https://doi.org/10.1016/j.ccc.2018.08.003

Keeffe, E. B. (2005). Acute liver failure. Revista de Gastroenterología de México, 70(1), 56-62.

Khanna, O., Larson, J. C., Moya, M. L., Opara, E. C., \& Brey, E. M. (2012). Generation of alginate microspheres for biomedical applications. Journal of Visualized Experiments, (66), 1-5. https://doi.org/10.3791/3388

Li, Y., Yang, G., \& Mei, Z. (2012). Spectroscopic and dynamic light scattering studies of the interaction between pterodontic acid and bovine serum albumin. Acta Pharmaceutica Sinica B, 2(1), 53-59. 
https://doi.org/10.1016/j.apsb.2011.12.001

Lou, R., Yu, W., Song, Y., Ren, Y., Zheng, H., Guo, X., ... Ma, X. (2017). Fabrication of stable galactosylated alginate microcapsules via covalent coupling onto hydroxyl groups for hepatocytes applications. Carbohydrate $\quad$ Polymers, $\quad$ 456-465, https://doi.org/10.1016/j.carbpol.2016.08.098

McIntosh, M. B., Corner, S. M., Amiot, B. P., \& Nyberg, S. L. (2009). Engineering analysis and development of the spheroid reservoir bioartificial liver. Proceedings of the 31st Annual International Conference of the IEEE Engineering in Medicine and Biology Society: Engineering the Future of Biomedicine, EMBC, 5985-5988. https://doi.org/10.1109/IEMBS.2009.5334687

Nibourg, G. A. A., Hoekstra, R., Hoeven, T. V. V. Der, Ackermans, M. T., Hakvoort, T. B. M., Gulik, T. M. V., \& Chamuleau, R. A. F. M. (2013). Increased hepatic functionality of the human hepatoma cell lineHepaRG cultured in the AMC bioreactor. International Journal of Biochemistry and Cell Biology, 45(8), 1860-1868. https://doi.org/10.1016/j.biocel.2013.05.038

Pasqua, M., Pereira, U., Messina, A., de Lartigue, C., Vigneron, P., Dubart-Kupperschmitt, A., \& Legallais, C. (2020). HepaRG Self-Assembled Spheroids in Alginate Beads Meet the Clinical Needs for Bioartificial Liver. Tissue Engineering Part A, ahead of $p$, 1-33. https://doi.org/10.1089/ten.tea.2019.0262

Poyck, P. P. C., Hoekstra, R., van Wijk, A. C. W. A., Attanasio, C., Calise, F., Chamuleau, R. A. F. M., \& van Gulik, T. M. (2007). Functional and morphological comparison of three primary liver cell types cultured in the AMC bioartificial live. Liver Transplantation, 13(4), 589-598. https://doi.org/10.1002/lt.21090

Rebelo, S. P., Costa, R., Estrada, M., Shevchenko, V., Brito, C., \& Alves, P. M. (2015). HepaRG microencapsulated spheroids in DMSO-free culture: novel culturing approaches for enhanced xenobiotic and biosynthetic metabolism. Archives of Toxicology, 89(8), 1347-1358. https://doi.org/10.1007/s00204-014-1320-9

Selden, C., Bundy, J., Erro, E., Puschmann, E., Miller, M., Kahn, D., ... Spearman, C. W. (2017). A clinical-scale BioArtificial Liver, developed for GMP, improved clinical parameters of liver function in porcine liver failure. Scientific Reports, 7(1), 1-19. https://doi.org/10.1038/s41598- 
$017-15021-4$

Simó, G., Fernández-Fernández, E., Vila-Crespo, J., Ruipérez, V., \& Rodríguez-Nogales, J. M. (2017). Research progress in coating techniques of alginate gel polymer for cell encapsulation. Carbohydrate Polymers, 170, 1-14. https://doi.org/10.1016/j.carbpol.2017.04.013

Strand, B. L., Ryan, L., In’t Veld, P., Kulseng, B., Rokstad, A. M., Skjåk-Bræk, G., \& Espevik, T. (2001). Poly-L-lysine induces fibrosis on alginate microcapsules via the induction of cytokines. Cell Transplantation, 10(3), 263-275. https://doi.org/10.3727/000000001783986800

Strand, Berit L., Coron, A. E., \& Skjak-Braek, G. (2017). Current and future perspectives on alginate encapsulated pancreatic islet. Stem Cells Translational Medicine, 6(4), 1053-1058. https://doi.org/10.1002/sctm.16-0116

Tam, S. K., Bilodeau, S., Dusseault, J., Langlois, G., Hallé, J. P., \& Yahia, L. H. (2011). Biocompatibility and physicochemical characteristics of alginate-polycation microcapsules. Acta Biomaterialia, 7(4), 1683-1692. https://doi.org/10.1016/j.actbio.2010.12.006

Tostões, R. M., Leite, S. B., Serra, M., Jensen, J., Björquist, P., Carrondo, M. J. T., ... Alves, P. M. (2012). Human liver cell spheroids in extended perfusion bioreactor culture for repeated-dose drug testing. Hepatology, 55(4), 1227-1236. https://doi.org/10.1002/hep.24760

Tran, N. M., Dufresne, M., Helle, F., Hoffmann, T. W., Francois, C., Brochot, E., ... Castelain, S. (2014). Alginate hydrogel protects encapsulated hepatic $\mathrm{HuH}-7$ cells against hepatitis $\mathrm{C}$ virus and other viral infections. PLoS ONE, 9(10), 16-17. https://doi.org/10.1371/journal.pone.0109969

Van De Kerkhove, M. P., Poyck, P. P. C., Deurholt, T., Hoekstra, R., Chamuleau, R. A. F. M., \& Van Gulik, T. M. (2005). Liver support therapy: An overview of the AMC-bioartificial liver research. Digestive Surgery, 22(4), 254-264. https://doi.org/10.1159/000088055

van Wenum, M., Adam, A. A. A., van der Mark, V. A., Chang, J. C., Wildenberg, M. E., Hendriks, E. J., ... Hoekstra, R. (2018). Oxygen drives hepatocyte differentiation and phenotype stability in liver cell lines. Journal of Cell Communication and Signaling, 12(3), 575-588. https://doi.org/10.1007/s12079-018-0456-4

Van Wenum, M., Chamuleau, R. A., Van Gulik, T. M., Siliakus, A., Seppen, J., \& Hoekstra, R. (2014). Bioartificial livers in vitro and in vivo: Tailoring biocomponents to the expanding variety of 
applications. Expert Opinion on Biological Therapy, 14(12), 1745-1760. https://doi.org/10.1517/14712598.2014.950651

Wang, N., Adams, G., Buttery, L., Falcone, F. H., \& Stolnik, S. (2009). Alginate encapsulation technology supports embryonic stem cells differentiation into insulin-producing cells. Journal of Biotechnology, 144(4), 304-312. https://doi.org/10.1016/j.jbiotec.2009.08.008

Wisse, F. B. and E. (2002). Structural and functional aspects of liver sinusoidal endothelial cell fenestrae: a review. Comp Hepatol, 1(1). https://doi.org/10.1186/1476-5926-1-1

Zhou, P., Shao, L., Zhao, L., Lv, G., Pan, X., Zhang, A., ... Li, L. (2016). Efficacy of Fluidized Bed Bioartificial Liver in Treating Fulminant Hepatic Failure in Pigs: A Metabolomics Study. Scientific Reports, 6(1), 1-9. https://doi.org/10.1038/srep26070 
Tables:

Table 1: Fluorescent molecules with their characteristics used to investigate bead permeability. DH indicates the hydrodynamic diameter of the protein without the fluorophore; MW indicates the molecular weight.

\begin{tabular}{|c|c|c|c|c|}
\hline Fluorescent marker & Supplier & Molecular weight or size & Concentration & Reference \\
\hline $\begin{array}{l}\text { Albumin-fluorescein } \\
\text { isothiocyanate } \\
\text { (FITC) }\end{array}$ & Sigma-Aldrich & $\begin{array}{c}\mathrm{D}_{\mathrm{H}}=7.3 \mathrm{~nm}(\mathrm{Li}, \text { Yang, \& } \\
\text { Mei, 2012); MW =66 } \\
\mathrm{kDa}\end{array}$ & $\begin{array}{l}100 \mu \mathrm{g} / \mathrm{mL} \text { in } \mathrm{WE} \\
\text { medium at } 37^{\circ} \mathrm{C}\end{array}$ & \multirow{2}{*}{$\begin{array}{l}\text { (Wang, } \\
\text { Adams, } \\
\text { Buttery, } \\
\text { Falcone, } \\
\text { \& Stolnik, } \\
\text { 2009) }\end{array}$} \\
\hline $\begin{array}{c}\text { Alexa Fluor } 488 \\
\text { conjugate IgG }\end{array}$ & Thermofisher & $\begin{array}{c}\mathrm{D}_{\mathrm{H}}=11.5 \mathrm{~nm} \text { (Gagnon, } \\
\text { Nian, Leong, \& Hoi, } \\
2015) ; \mathrm{MW}=160 \mathrm{kDa}\end{array}$ & $\begin{array}{l}100 \mu \mathrm{g} / \mathrm{mL} \text { in } \mathrm{WE} \\
\text { medium at } 37^{\circ} \mathrm{C}\end{array}$ & \\
\hline Nanoparticles (NPs) & $\begin{array}{l}\text { Estapor, Merk } \\
\text { Chimie }\end{array}$ & $\begin{array}{c}41 \mathrm{~nm} \\
103 \mathrm{~nm} \\
249 \mathrm{~nm}\end{array}$ & $\begin{array}{l}340 \mu \mathrm{g} / \mathrm{mL} \text { in } \mathrm{WE} \\
\text { medium at room } \\
\text { temperature }\end{array}$ & $\begin{array}{l}\text { (Tran et } \\
\text { al., 2014) }\end{array}$ \\
\hline
\end{tabular}

Table 2: Media for metabolic characterization on day 14 post-encapsulation and tests performed.

\begin{tabular}{cc|c|c} 
HepaRG proliferation & $\begin{array}{c}\text { Test medium } \\
\text { culture medium }\end{array}$ & $\begin{array}{c}\text { Human equivalent } \\
\text { pathological plasma medium }\end{array}$ \\
\hline $\begin{array}{c}\text { Medium } \\
\text { composition }\end{array}$ & $\begin{array}{c}\text { William's E medium }+ \\
\text { Biopredic } 710 \\
\text { proliferation media }\end{array}$ & $\begin{array}{c}\text { HepaRG proliferation culture } \\
\text { medium }+1.5 \mathrm{mM} \text { ammonium } \\
\text { chloride }+2 \mathrm{mM} \mathrm{L-Lactate}\end{array}$ & $\begin{array}{c}\text { HepaRG proliferation culture } \\
\text { medium }+70 \mathrm{~g} / \mathrm{L} \text { bovine serum } \\
\text { albumin }+1.5 \mathrm{mM} \text { ammonium } \\
\text { chloride }+2 \mathrm{mM} \mathrm{L-Lactate}\end{array}$ \\
\hline $\begin{array}{c}\text { Metabolic } \\
\text { performances } \\
\text { tested } \\
\text { (Test duration })\end{array}$ & $\begin{array}{c}\text { Albumin synthesis rate } \\
(2 \mathrm{~h})\end{array}$ & $\begin{array}{c}\text { Albumin synthesis rate } \\
(2 \mathrm{~h})\end{array}$ & $\begin{array}{c}\text { Albumin synthesis rate } \\
(6 \mathrm{~h})\end{array}$ \\
\cline { 2 - 4 } & $\begin{array}{c}\text { CYP clearance rate } \\
(1 \mathrm{~h})\end{array}$ & $\begin{array}{c}\text { Ammonia detoxification rate } \\
(2 \mathrm{~h})\end{array}$ & $\begin{array}{c}\text { Ammonia detoxification rate } \\
(6 \mathrm{~h})\end{array}$ \\
\hline
\end{tabular}

Table 3: Summary of metabolic activities between biomass in alginate beads with and without a PLL coating. Activities tested on day 14 post-encapsulation in shaken conditions, in HepaRG proliferation culture medium, and in test medium. $\mathrm{N}>3$

\begin{tabular}{|c|c|c|c|c|c|c|}
\hline \multirow[b]{2}{*}{$\begin{array}{c}\text { Biomass } \\
\left(5 \times 10^{6} \text { cells }\right)\end{array}$} & \multicolumn{3}{|c|}{ HepaRG proliferation culture medium } & \multicolumn{3}{|c|}{ Test medium } \\
\hline & $\begin{array}{c}\text { Albumin } \\
\text { synthesis rate } \\
\left(\mu \mathrm{g} / \mathrm{h} / \mathbf{1 0}^{6}\right)\end{array}$ & $\begin{array}{c}\text { ICG } \\
\text { releasing rate } \\
\left(\mu \mathrm{g} / \mathrm{h} / \mathbf{1 0}^{6}\right)\end{array}$ & $\begin{array}{c}\text { CYP 1A1/2 } \\
\text { activity } \\
\left(\mathrm{pmol} / \mathrm{h} / \mathbf{1 0}^{6}\right)\end{array}$ & $\begin{array}{l}\text { Albumin } \\
\text { synthesis } \\
\text { rate } \\
\left(\mu \mathrm{g} / \mathrm{h} / \mathbf{1 0}^{6}\right)\end{array}$ & $\begin{array}{c}\text { Ammonia } \\
\text { detoxification } \\
\text { rate } \\
\left(\mathbf{n m o l} / \mathbf{h} / \mathbf{1 0}^{6}\right)\end{array}$ & $\begin{array}{c}\text { Lactate } \\
\text { clearance } \\
\text { rate } \\
\left(\mathbf{n m o l} / \mathbf{h} / \mathbf{1 0}^{6}\right)\end{array}$ \\
\hline $\begin{array}{l}\text { Alginate beads } \\
\text { without PLL } \\
\text { coating }\end{array}$ & $0.85 \pm 0.42$ & $45.3 \pm 6.9$ & $6.5 \pm 1.9$ & $0.43 \pm 0.19$ & $90.4 \pm 61.0$ & $111.8 \pm 68.3$ \\
\hline $\begin{array}{l}\text { Alginate beads } \\
\text { with PLL } \\
\text { coating }\end{array}$ & $0.62 \pm 0.22$ & $20.9 \pm 7.8$ & $1.8 \pm 1.0$ & $0.56 \pm 0.24$ & $73.7 \pm 28.4$ & $95.6 \pm 50.4$ \\
\hline
\end{tabular}


Figure 1. A: Experimental setups allowing culture and metabolic characterization of the encapsulated biomass. Left: Shaken condition: Petri dish hosting $5 \times 10^{6}$ cells in $7.5 \mathrm{~mL}$ of surrounding medium kept in continuous orbital shaking (60 rpm). Right: Perfused dynamic bioreactor (PDB): double arm glass flask hosting $50 \times 10^{6}$ cells in $37.5 \mathrm{~mL}$ of total medium volume. The peristaltic pump (Ismatec) makes constant perfusion possible (flow rate $=0.4 \mathrm{~mL} / \mathrm{min}$ ) while the beads are kept in continuous orbital shaking $(80 \mathrm{rpm})$. The needles for media recirculation are protected with a filter membrane to avoid biomass escaping from the PDB. Two outlets are dedicated to filtered air intake to preserve sterility and guarantee gas exchanges. B: Experimental setup. After 2D amplification, cells were encapsulated in alginate beads and then cultivated for 14 days. Cell culture evolution was monitored analysing cell viability (by Live/Dead staining on days $0,1,7,14$ ) and albumin synthesis rate (overnight between days $0-1,6-7,9-10,13-14)$. On day 14 post-encapsulation, cell performance was tested by means of metabolic and xenobiotic tests in different media (HepaRG proliferation culture medium, test medium, and pathological plasma medium).

Figure 2. A: Distribution of PLL-rhodamine (red staining) in empty beads in comparison with the negative control (without PLL coating). Images taken in confocal microscopy (left images), phase contrast (central) and merging the two (right). Scale bar: $100 \mu \mathrm{m}$. B: Elastic modulus of the outer surface of empty beads with and without a PLL coating on day 14 . With an indentation of $3 \mu \mathrm{m}$, the sensor penetrated only into the PLL layer, when present. Significance was analysed using a Mann-Whitney Test. *** indicates $\mathrm{p}<0.001 . \mathrm{N}=10$ per batch of beads.

Figure 3. Permeability of empty beads (coated or not with PLL) to fluorescent markers (albumin, IgG, nanoparticles of different diameters). DH indicates the hydrodynamic diameter without the fluorophore; $\varnothing$ indicates the diameter of the nanoparticles (NPs). Incubation lasted 24 hours. Pictures taken after washing the beads in WE. Scale bar: $100 \mu \mathrm{m}$.

Figure 4. Observation of beads without and with PLL coating morphology by bright field microscopy (scale bar: $500 \mu \mathrm{m}$ ) and cell viability of alginate-PLL encapsulated cells (live/dead assay) by confocal 
microscopy. In green (Calcein AM): viable cells, in red (ethidium homodimer-1): dead cells, in blue (Hoechst 33342 dye): cell nuclei (scale bar $100 \mu \mathrm{m}$ ).

Figure 5. Metabolic activities of cells in alginate-PLL beads, measured on day 14, over 6 hours' incubation in equivalent pathological plasma medium, in shaken conditions and a perfused dynamic bioreactor (PDB). A: albumin synthesis rate; B: ammonia detoxification rate; C: lactate detoxification rate. 


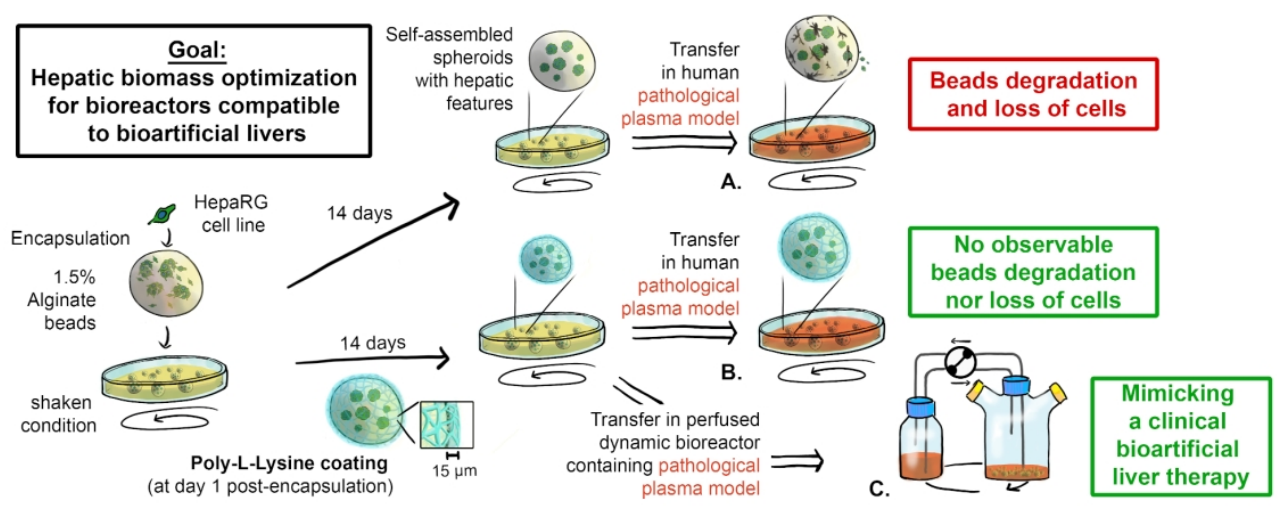

Graphical abstract

$168 \times 67 \mathrm{~mm}(300 \times 300$ DPI $)$ 


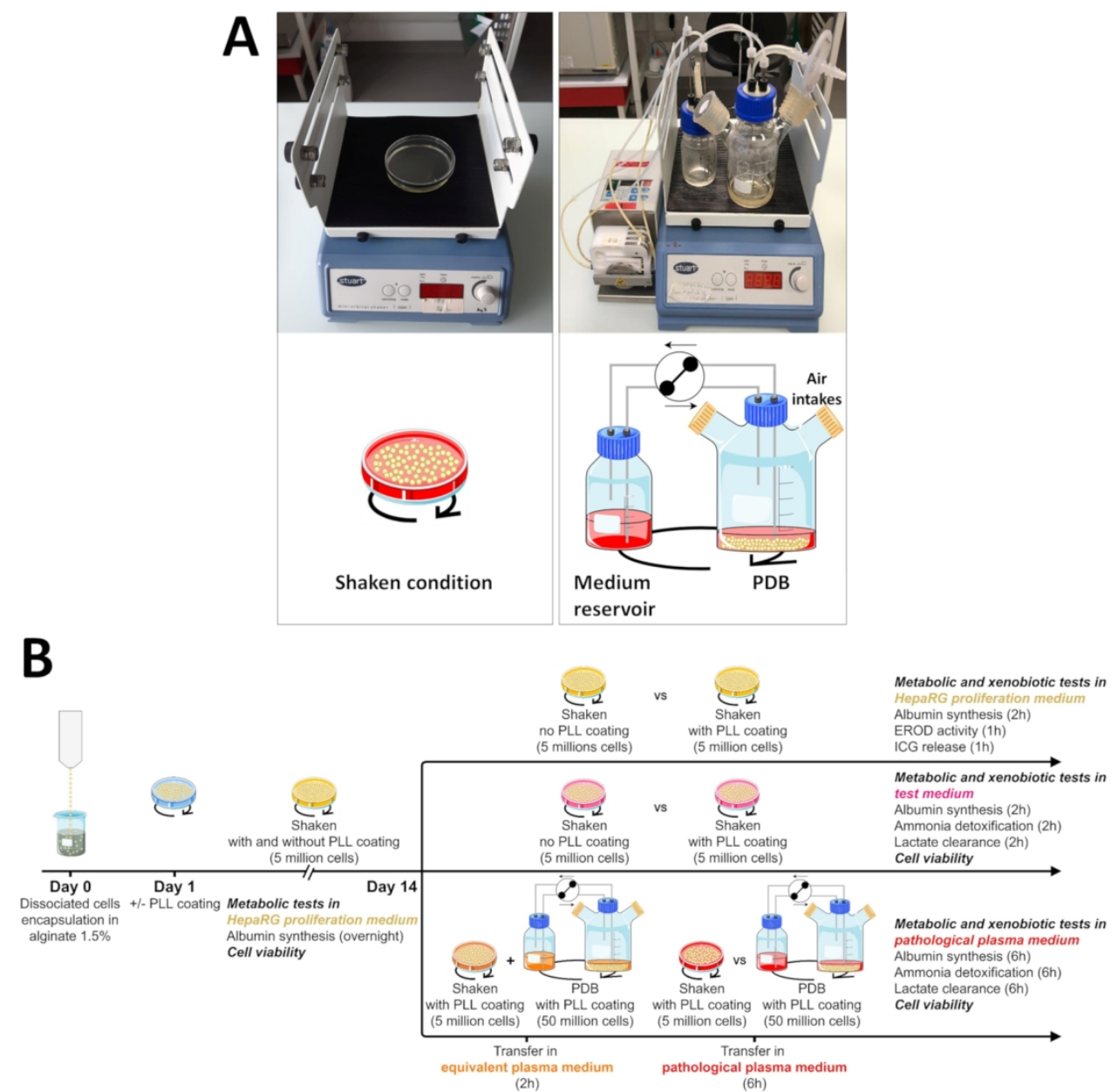

Figure 1. A: Experimental setups allowing culture and metabolic characterization of the encapsulated biomass. Left: Shaken condition: Petri dish hosting $5 \times 106$ cells in $7.5 \mathrm{~mL}$ of surrounding medium kept in continuous orbital shaking (60 rpm). Right: Perfused dynamic bioreactor (PDB): double arm glass flask hosting $50 \times 106$ cells in $37.5 \mathrm{~mL}$ of total medium volume. The peristaltic pump (Ismatec) makes constant perfusion possible (flow rate $=0.4 \mathrm{~mL} / \mathrm{min}$ ) while the beads are kept in continuous orbital shaking ( $80 \mathrm{rpm}$ ). The needles for media recirculation are protected with a filter membrane to avoid biomass escaping from the PDB. Two outlets are dedicated to filtered air intake to preserve sterility and guarantee gas exchanges. B: Experimental setup. After 2D amplification, cells were encapsulated in alginate beads and then cultivated for 14 days. Cell culture evolution was monitored analysing cell viability (by Live/Dead staining on days $0,1,7$, 14) and albumin synthesis rate (overnight between days 0-1,6-7, 9-10, 13-14). On day 14 postencapsulation, cell performance was tested by means of metabolic and xenobiotic tests in different media (HepaRG proliferation culture medium, test medium, and pathological plasma medium).

$149 \times 146 \mathrm{~mm}(300 \times 300 \mathrm{DPI})$ 

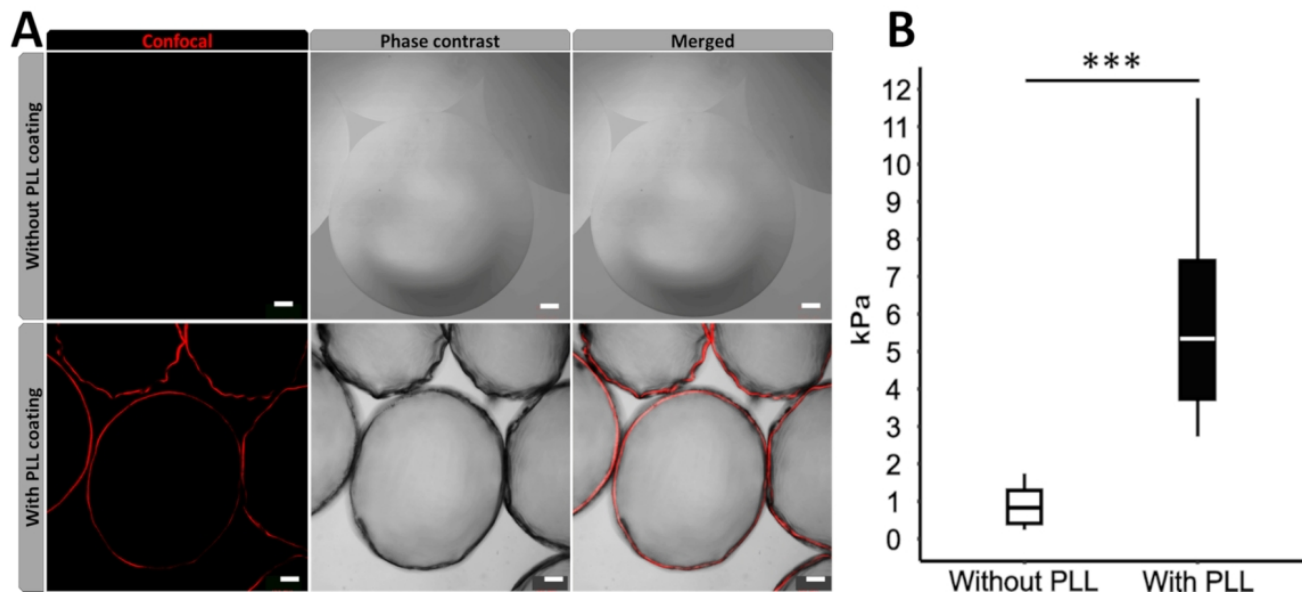

Figure 2. A: Distribution of PLL-rhodamine (red staining) in empty beads in comparison with the negative control (without PLL coating). Images taken in confocal microscopy (left images), phase contrast (central) and merging the two (right). Scale bar: $100 \mu \mathrm{m}$. B: Elastic modulus of the outer surface of empty beads with and without a PLL coating on day 14 . With an indentation of $3 \mu \mathrm{m}$, the sensor penetrated only into the PLL layer, when present. Significance was analysed using a Mann-Whitney Test. $* * *$ indicates $\mathrm{p}<0.001$. N $=10$ per batch of beads.

$149 \times 67 \mathrm{~mm}(300 \times 300 \mathrm{DPI})$ 


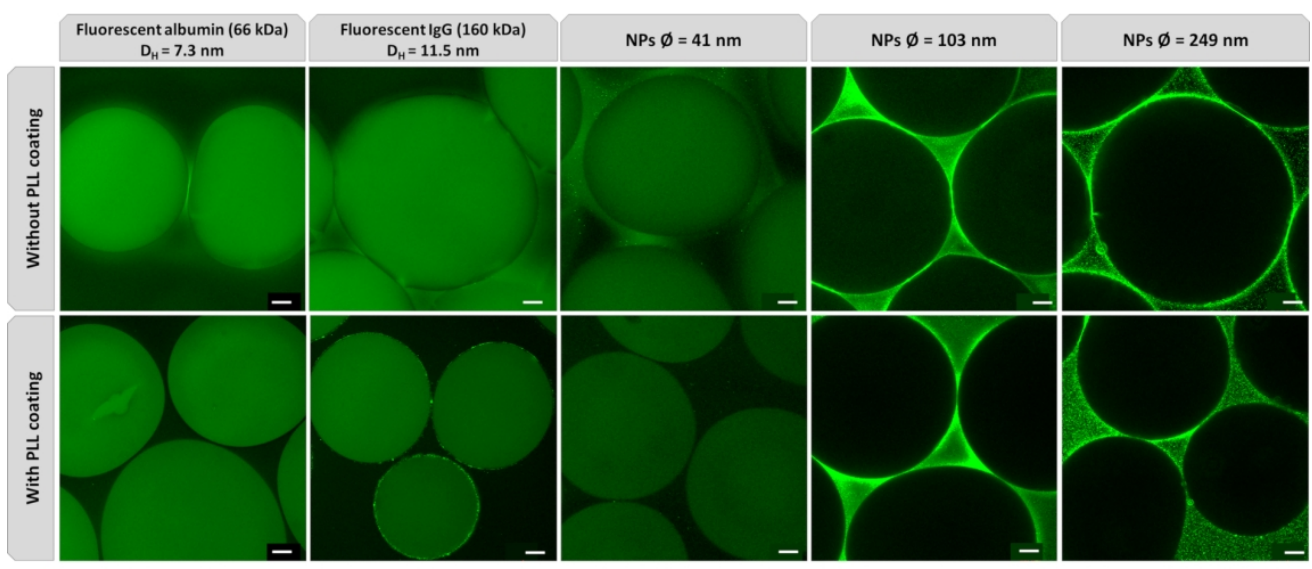

Figure 3. Permeability of empty beads (coated or not with PLL) to fluorescent markers (albumin, IgG, nanoparticles of different diameters). DH indicates the hydrodynamic diameter without the fluorophore; $\varnothing$ indicates the diameter of the nanoparticles (NPs). Incubation lasted 24 hours. Pictures taken after washing the beads in WE. Scale bar: $100 \mu \mathrm{m}$.

$$
159 \times 68 \mathrm{~mm}(300 \times 300 \text { DPI) }
$$




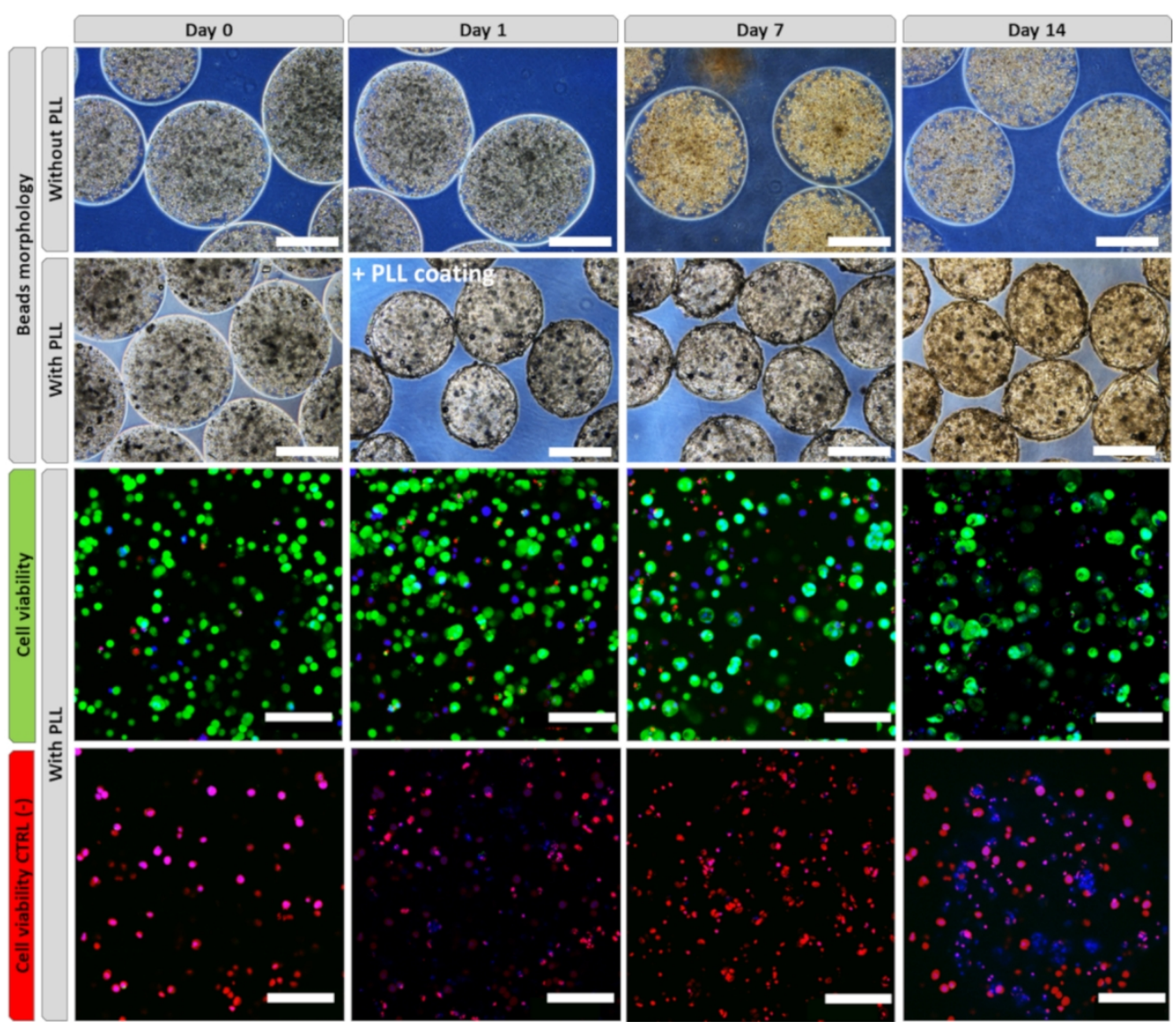

Figure 4. Observation of beads without and with PLL coating morphology by bright field microscopy (scale bar: $500 \mu \mathrm{m}$ ) and cell viability of alginate-PLL encapsulated cells (live/dead assay) by confocal microscopy. In green (Calcein AM): viable cells, in red (ethidium homodimer-1): dead cells, in blue (Hoechst 33342 dye): cell nuclei (scale bar $100 \mu \mathrm{m}$ ).

$149 \times 129 \mathrm{~mm}(300 \times 300 \mathrm{DPI})$ 
Figure 5. Metabolic activities of cells in alginate-PLL beads, measured on day 14, over 6 hours' incubation in equivalent pathological plasma medium, in shaken conditions and a perfused dynamic bioreactor (PDB). A: albumin synthesis rate; $\mathrm{B}$ : ammonia detoxification rate; C: lactate detoxification rate.

$71 \times 24 \mathrm{~mm}(600 \times 600 \mathrm{DPI})$ 
Figure 1, Supplementary Data. Albumin secretion rate over time (overnight between days 0-1, 6-7, 9-10, 13-14) of encapsulated cells in alginate beads with and without PLL coating. For the condition with PLL, the increasing between day 1 and da14 was significant $(* *$ indicates $\mathrm{p}<0.01$, significance analysed by Dunn's Multiple Comparisons Test). $\mathrm{N}>3$.

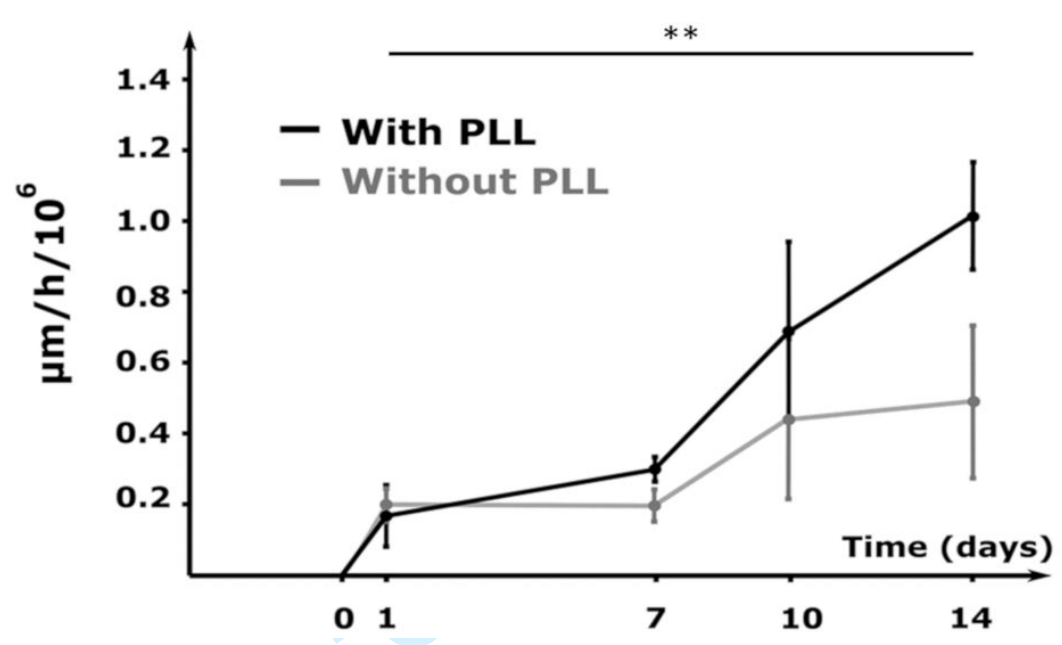

Figure 2, Supplementary Data. Cell viability (live/dead assay) of cells in alginate beads without and with PLL coating in shaken and PDB setups by confocal microscopy, after exposure to different culture media. In green (Calcein AM): viable cells, in red (ethidium homodimer-1): dead cells, in blue (Hoechst 33342 dye): cell nuclei. Scale bar: $100 \mu \mathrm{m}$.

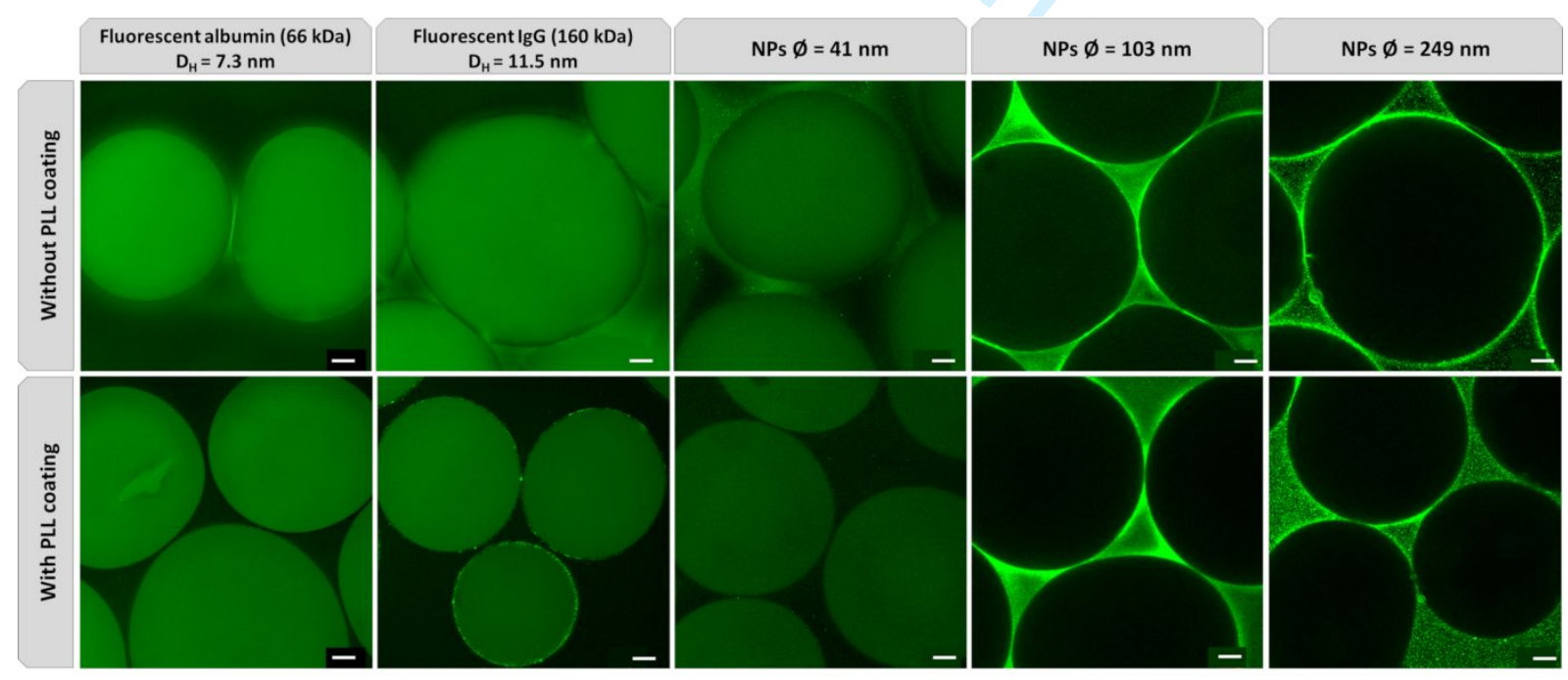

